\title{
An Application of Immuno Peroxidase Staining Technique for the Titration of Dengue Virus in vitro
}

\author{
Tomiyoshi Ito, Eiki Tanimura, Yukio Ohsugi, Kohei Maeda, \\ Fuminori Hirata and Akio Ohyama \\ Department of Microbiology, Kansai Medical University, \\ Moriguchi, Osaka, Japan \\ (Received for publication September 30, 1986) \\ Key words : Dengue virus, Immuno peroxidase staining, Titration, EFFA
}

\begin{abstract}
SUMMARY
A newly modified enzyme focus forming assay (EFFA) has been developed for the titration of dengue viruses (DV). Infectious foci were stained with peroxidase labeled antibody and colorized with Karnovsky's solution. The foci were easy to count by the naked eye and were semipermanently preserved. The EFFA was compared either with conventional plaque assay or with suckling mouse intracerebral inoculation for the sensitivity and for the incubation period. The EFFA was higher in sensitivity and reduced the incubation period more than 2 days in DV titration. Therefore the EFFA was useful for the titration especially of non/weakcytopathogenic viruses. The method was also useful for the ultrastructural study of viral replication in electron microscopy. The variables affecting the assay were investigated.
\end{abstract}

\section{INTRODUCTION}

The plaque formation in viral infectious experiments has been utilized not only for the viral titration but also for the detection of mutant strains such as pathogenic variants. However, when the cytotoxity is weak or absent in the virus-host combination, it is difficult to form plaques. And the plaque formation requires longer incubation for titration of such viruses as dengue virus (DV) ${ }^{14)}$.

To overcome this difficulty, immunocytochemical techniques have been applied. Igarashi and Mantani ${ }^{7)}$ have developed a new method of counting fluorescent foci on the virus infected cultured cells. Although their method is useful in titrating the viral infectivity and save the incubation time, it has some disadvantages. A fluorescense microscope is necessary and it is useful only for the analysis of the viruses which spread by the cell to cell infection. 
We have now developed a new method, the Enzyme focus forming assay (EFFA), in which we combined the plaque forming assay (PFA) 2) 5) 17) and the enzyme labeled antibody assay system ${ }^{13}{ }^{14}$ ). The EFFA enable one to resoleve the above mentioned problems and has more advantages for the morphological study ${ }^{12)}{ }^{18)}$.

In the present study, we have compared the results of our new method with those of the previous conventional methods using Japanese encephalitis virus (cytopathogenic virus ; JEV), and DVs (weak cytopathogenic viruses). The variables affecting the analysis have been investigated and some experiments are presented.

\section{MATERIALS AND METHODS}

\section{Cells}

Vero cells were subcultured in Eagle's minimum esssential medium (MEM), supplemented with $10 \%$ calf serum, penicillin $(100 \mathrm{U} / \mathrm{ml})$ and streptomycin $(100 \mu \mathrm{g} / \mathrm{ml})$. For the virus inoculated cells, $2 \%$ calf serum was supplemented to MEM.

\section{Viruses}

JEV, JaGAr-01 strain, was obtained from Dr. T. Kurimura*, Osaka Prefectural Institute of Public Health. DVs, type I (D-I) Hawaii strain, type II (D-II) Tr 1751 strain, type III (D-III) H-87 strain and type IV (D-IV) H-241 strain, were obtained from Dr. K. Fukai, Institute of Microbial Diseases, Osaka University. All viruses in suckling mouse brain (SMB) were passed either in SMB or in Vero cells for 5 times. Ten percent of infected SMB emulsion was prepared with Hanks' balanced salt solution supplemented with $0.5 \%$ bovine serum albumin (Fraction V, Sigma, St. Louis, MO), penicillin and streptomycin at $100 \mathrm{U} / \mathrm{ml}$ and $100 \mu \mathrm{g} / \mathrm{ml}$, respectively (HBSA). The emulsion was centrifuged at $5,000 \mathrm{rpm}$ for $5 \mathrm{~min}$ at $4^{\circ} \mathrm{C}$. The supernatant was distributed and stored at $-80^{\circ} \mathrm{C}$ until use. Virus infected Vero cells were frozen and thawed for 3 times using dryice-acetone $\left(-70^{\circ} \mathrm{C}\right)$ and water, then they were centrifuged at $5,000 \mathrm{rpm}$ for $5 \mathrm{~min}$ at $4^{\circ} \mathrm{C}$. Each supernatant was distributed and stored at $-80^{\circ} \mathrm{C}$ untile use.

\section{Antisera}

Antiserum to each virus was prepared in male white rabbits. The procedures have been described elswhere ${ }^{8)}$. The immunoglobulin G (IgG) fraction was precipitated with the $1 / 3$ satulated ammonium sulfate. IgG was absorbed nonspecific agents with Vero cell acetone powder and mouse liver acetone powder. Horseradish peroxidase (HRPO) labeled anti-rabbit IgG goat IgG (Miles-Yeda, Israel) was used for the second serum in the indirect method.

* Present affiliation : Department of Virology, Faculty of Medicine, Tottori University. 


\section{Virus infection}

Vero cells were suspended in MEM $\left(2 \times 10^{5}\right.$ cells $\left./ \mathrm{ml}\right)$ and were dispensed into wells of plastic multiwell plate $(4 \times 6$ wells, Nunc, Denmark $)$ for $1 \mathrm{ml}$ each. The plates were incubated at $37^{\circ} \mathrm{C}$ in a $\mathrm{CO}_{2}$ incubator. A $0.1 \mathrm{ml}$ of serially ten fold diluted virus suspension was absorbed for $90 \mathrm{~min}$ at $37^{\circ} \mathrm{C}$. After the incubation, $1 \mathrm{ml}$ of the overlay medium, containing 1. $0-1.8 \%$ methylcelluolose and $2 \%$ calf serum, was added to each well. Plates were incubated in a $\mathrm{CO}_{2}$ incubator for 2 to 7 days.

\section{Plaque assay}

After the suitable incubation, the overlay medium was removed. The cells were washed with cold PBS and were fixed with cold methanol for $10 \mathrm{~min}$. The wells were divided into two groups, one for the PFA and the other for the EFFA. In the PFA, the cells were stained with Giemsa solution.

\section{Focus staining method with enzyme labeled antibody}

The flow chart of the EFFA was shown in Table 1. A drop of goat normal serum $(1: 50)$ was mounted on the fixed cells of each well to prevent nonspecific adsorption of HRPO labeled IgG. Then a $0.1 \mathrm{ml}$ of anti-viral IgG suspension, diluted with PBS for appropriate concentration, was added to each well. HRPO labeled anti-rabbit IgG goat IgG was used in the second reaction. In every step, plates were incubated at $37^{\circ} \mathrm{C}$ for $30 \mathrm{~min}$ in a moist chamber. After the incubation, wells were washed with PBS which was supplemented with

Table 1. Flow chart describing the focus-staining method using peroxidase labeled antibody (Enzyme Focus Forming Assay ; EFFA)

Multiwell plate with the confluent Vero cell monolayer.

Infect with serially diluted virus.

Incubate at $37^{\circ} \mathrm{C}$ for 3 to 7 days with $5 \% \mathrm{CO}_{2}$.

Remove overlay medium and wash each well 3 times with cold PBS at $4^{\circ} \mathrm{C}$ and blot.

Fix with cold methanol $\left(-20^{\circ} \mathrm{C}\right)$ for $10 \mathrm{~min}$.

Dispense normal goat sera to each well ${ }^{\mathrm{a}}$ and incubate at $37^{\circ} \mathrm{C}$ for $30 \mathrm{~min}$.

Wash 3 times for $15 \mathrm{~min}$ each time with cold $\mathrm{PBS} / \mathrm{T} / \mathrm{BSA}^{\mathrm{b}}$ at $4^{\circ} \mathrm{C}$.

Dispense the dilute primary serac to each well and incubate at $37^{\circ} \mathrm{C}$ for $30 \mathrm{~min}$.

Wash 3 times for $15 \mathrm{~min}$ each time with cold $\mathrm{PBS} / \mathrm{T} / \mathrm{BSA}$ at $4^{\circ} \mathrm{C}$.

Dispense the dilute secondary sera to each well and incubate at $37^{\circ} \mathrm{C}$ for $30 \mathrm{~min}$.

Wash 3 times for 15 min each time with cold PBS/T/BSA.

Stain with Karnovsky's solutione at room temperature.

a : $0.1 \mathrm{ml} /$ well for 24 wells $(\psi=16 \mathrm{~mm})$ plate.

b : PBS, pH 7.2 with $0.05 \%$ Tween-20 and $0.5 \%$ bovine serum albumin.

c : Anti-virus rabbit IgG.

d : HRPO labeled anti-rabbit IgG goat IgG. (Miles-Yeda, Israel).

e : $0.05 \mathrm{M}$ Tris- $\mathrm{HCl}$ buffer, $\mathrm{pH} 7.6$ with $0.02 \% 3,3^{\prime}$-diaminobenzidine $4 \mathrm{HCl}$ and $0.01 \% \mathrm{H}_{2} \mathrm{O}_{2}$. 
$0.05 \%$ Tween-20 and $0.5 \%$ boving serum albumin (PBS/T/BSA) for 3 times for $15 \mathrm{~min}$ each time. For colorizing the infectious foci Karnovsky's substrate solution ${ }^{4}$ was used and kept at room temperature (Table 1).

\section{Mouse intracerebral inoculation}

Serially 10 fold diluted DVs were inoculated to 1-2 days old suckling mice intracerebrally ${ }^{6)}$. Fifty percent lethal dose $\left(\mathrm{LD}_{50}\right)$ was calculated by Reed and Muench ${ }^{16)}$.

\section{Electron microscopy of the infectious foci}

Specimen for the electron microscopy was prepared with a slight modification in fixation. After incubation for 4 days, the foci of D-II infection were prefixed at $4^{\circ} \mathrm{C}$ for $2 \mathrm{~h}$ with periodate-lysin-paraformaldehyde ${ }^{11)}$ which was supplemented with $0.1 \%$ glutaraldehyde $^{18)}$. The immunoenzymatic process was followed by the method described above. But antisera were reacted at $4^{\circ} \mathrm{C}$ for overnight in stead of the incubation at $37^{\circ} \mathrm{C}$ for $30 \mathrm{~min}$. Foci were post fixed with $1 \% \mathrm{OsO}_{4}$ at $4^{\circ} \mathrm{C}$ for $2 \mathrm{~h}$, were dehydrated and were embeded in Epon 812 resin ${ }^{10)}$. The virus infected cells were easily trimmed under a converted microscope. Ultrathin sections were observed with or without staining with uranyl acetate and lead citrate $^{3)}$. They were observed under a Hitachi electron microscope model $\mathrm{H} 500$ operating at $100 \mathrm{kv}$.

\section{RESULTS}

\section{Comparative sensitivity of the EFFA for titration of JEV}

Plaque or focus size, incubation period and viral titers as detected by the PFA or by the EFFA were compared on JEV. Concentration of methylcellulose (MC) was $1.5 \%$ both in the EFFA and in the PFA accroding to Hsue ${ }^{5)}$. By the PFA, plaques were detected after incubation for 4 days with the size of $0.2-0.4 \mathrm{~mm}$ in diameter. The size enlarged to $0.6-0.8$ $\mathrm{mm}$ in 5 days of incubation. While the infectious focus in the EFFA was observed 2 days after inoculation and the diameter was about $0.2 \mathrm{~mm}$. After incubation for 5 days, the focus was a doughnut-like shape, with $0.15-0.2 \mathrm{~mm}$ in width and $1.2-1.4 \mathrm{~mm}$ in the outer diameter (Fig. 1). Microscopic observation of this focus showed that the central less dense area was based on the virus cytopathic effect (CPE) and that the cells were stripped off from the plate. While the marginal zone of the focus was partially healthy in spite of the virus infection. Therefore the cells were stained as antigen positive (data is not shown).

The prolonged incubation affected only the focus size and did not the focus number. The viral titer was kept in the same level through the incubation time. There were no differences in the infectious titer of the original JEV in SMB between two assay system (Table 2 and Fig. 1). 
Table 2. The comparison of viral titer and focus size between the EFFA and the PFA on Vero cells after JEV inoculation, and the effect of incubation time on them

\begin{tabular}{|c|c|c|c|c|c|c|c|}
\hline & & \multicolumn{6}{|c|}{ Days after inoculation } \\
\hline & & 1 & 2 & 3 & 4 & 5 & 7 \\
\hline \multirow{2}{*}{$\begin{array}{r}\text { Plaque } \\
\text { assay }\end{array}$} & Plaque size (mm) & $N^{a}{ }^{a}$ & invisible & invisible & $0.2-0.4$ & $0.6-0.8$ & $1.0-1.2$ \\
\hline & viral titer $(\mathrm{PFU} / \mathrm{ml})$ & NT & - & - & $2.0 \times 10^{7}$ & $1.8 \times 10^{7}$ & $2.1 \times 10^{7}$ \\
\hline \multirow{2}{*}{$\begin{array}{c}\text { EFFA } \\
\text { assay }\end{array}$} & Focus size $(\mathrm{mm})$ & NT & 0.2 & $0.4-0.6$ & $0.6-0.8$ & $1.2-1.4$ & $1.4-1.8$ \\
\hline & Viral titer $(\mathrm{EFFU} / \mathrm{ml})$ & NT & $1.8 \times 10^{7}$ & $2.2 \times 10^{7}$ & $2.0 \times 10^{7}$ & $2.0 \times 10^{7}$ & $1.9 \times 10^{7}$ \\
\hline
\end{tabular}

a : Not tested.

\section{Concentration of MC in the overlay medium}

Effects of the concentration of MC on the EFFA was investigated (Table 3). After incubation for 3 days, the foci with diameters of $0.2 \mathrm{~mm}$ or less were easily observed in all strains of DV. Variations of the concentration of MC did not affect the focus size nor shape. But after incubation for 5 days, those incubated with $1.0 \%$ of MC showed unclear foci while those with $1.2-1.8 \%$ formed clearly defined foci with diameters of $0.6-0.8 \mathrm{~mm}$. After incubation for 7 days, foci of $1.8 \% \mathrm{MC}$ were slightly smaller than those of either $1.2 \%$ or $1.5 \% \mathrm{MC}$.

\section{The incubation time and the focus size of DV}

To obtaine the optimum incubation time for the EFFA, the foci were fixed and stained at

Table 3. The effect of concentration of methylcellulose in the overlay medium on the focus size of DVs on Vero cell

\begin{tabular}{c|c|cccc}
\hline \multirow{2}{*}{ Virus } & $\begin{array}{c}\text { Days after } \\
\text { inoculation }\end{array}$ & \multicolumn{4}{|c}{ Concentration of methylcellulose $(\%)$} \\
\cline { 2 - 6 } D-I & 3 & 1.0 & 1.2 & 1.5 & 1.8 \\
\hline \multirow{5}{*}{ D-II } & 5 & $0.4-0.6$ & $0.6-0.8^{*}$ & $0.6-0.8^{*}$ & $0.4-0.6$ \\
& 7 & $1.0-1.6$ & $1.4-1.6$ & $1.2-1.4$ & $1.2-1.4$ \\
& 3 & 0.2 & 0.2 & 0.2 & 0.2 \\
& 5 & $0.8-1.0$ & $0.6-0.8^{*}$ & $0.6-0.8^{*}$ & $0.6-0.8$ \\
D-III & 7 & $1.2-1.6$ & $1.2-1.4$ & $1.6-1.8$ & $1.0-1.2$ \\
& 3 & $<0.2$ & $<0.2$ & $<0.2$ & $<0.2$ \\
& 5 & $0.4-0.6$ & $0.6-0.8^{*}$ & $0.6-0.8^{*}$ & $0.6-0.8$ \\
& 7 & $1.4-1.6$ & $1.2-1.4$ & $1.2-1.4$ & $1.0-1.2$ \\
D-IV & 3 & 0.2 & 0.2 & 0.2 & 0.2 \\
& 5 & $0.6-0.8$ & $0.6-0.8^{*}$ & $0.6-0.8^{*}$ & $0.6-0.8$ \\
& 7 & $1.4-1.6$ & $1.2-1.4$ & $1.0-1.4$ & $0.6-1.0$ \\
\hline
\end{tabular}

a : Focus size (mm).

*: Fine focus. 
3, 5 and 7 days after DV inoculation (Table 3). After incubation for 3 days, foci of DVs were detected by the EFFA, though the diameter was smaller than $0.2 \mathrm{~mm}$. The prolonged incubation caused larger foci in each strain of DV. After incubation for 5 days, foci were uniform and were easily countable (Table 3 and Fig. 2). But foci were sometimes unclear after incubation for 7 days. On the other hands, no plaques were formed by the PFA until 7 days after inoculation in all DV strains used in this study (data are not shown).

Effect of host cell in which the test virus prepared

In applying the EFFA for viral titration, effect of host cell, in which the test virus multiplied, on the focus formation was investigated. As shown in Table 4, the difference of the viral source did not affect the focus formation by D-I and D-III or a little (D-II and D-IV).

Assay of infectious titer of DVs by the EFFA and comparison to suckling

Table 4. The comparison of the focus size between SMB passed and Vero cell passed DVs by the EFFA*

\begin{tabular}{|c|c|c|}
\hline \multirow{2}{*}{ Virus } & \multicolumn{2}{|c|}{ Source of viruses, replicated in } \\
\hline & SMB & Vero \\
\hline$D-I$ & $0.6-0.8^{\mathrm{a})}$ & $0.6-0.8$ \\
\hline $\mathrm{D}-\mathrm{II}$ & $0.4-0.6$ & $0.6-0.8$ \\
\hline D-III & $0.6-0.8$ & $0.6-0.8$ \\
\hline D-IV & $0.4-0.6$ & $0.6-0.8$ \\
\hline
\end{tabular}

* : The infectious focus was stained 5 days after the incubation.

a : Focus size (mm). mouse brain inoculation assay

The EFFA was compared with suckling mouse brain inoculation assay (SMBA) for the sensitivity. Serially 10 fold diluted viruses which were passed in Vero cells were inoculated to Vero cells and into suckling mouse brain. Incubation time, required for the titration by both methods, were compared as shown in Table 5. In addition, the infectious titer by the EFFA (EFFU) and by the SMBA $\left(\mathrm{LD}_{50}\right)$ were compared on the aliquot of the material. The focus was detected after incubation for 3 days though the diameter was smaller than $0.2 \mathrm{~mm}$. The infectious titer was about $10^{8} \mathrm{EFFU} / \mathrm{ml}$ for 4 strains of DV. To the contrary, the mouse showed typical clinical signs 4 days after inoculation and died 5 to 6 days after inoculation. The $\mathrm{LD}_{50}$ was about $10^{8} / \mathrm{ml}$ for $\mathrm{D}-\mathrm{I}$, II and IV, $10^{7} / \mathrm{ml}$ for D-III.

\section{Electron microscopy of the infectious focus}

As shown in Fig. 4, characteristic tubular or small vesicular structures which sometimes appeared in the Togavirus infected cells were stained heavily on the cells located at the central zone of the foci. Some vesicles contained mature or budding viral particles.

On the surface of the cells which located marginal zone of the foci, viral particles attached to the cell membrane or penetrating particles through the coated pit were observed. And the cell surface was stained heavily. 
Table 5. The comparison of sensitivity in viral titration between the EFFA and the SMB inoculation method*.

\begin{tabular}{|c|c|c|c|c|c|c|c|c|}
\hline \multirow{2}{*}{$\begin{array}{l}\text { Days after } \\
\text { inoculation }\end{array}$} & \multicolumn{4}{|c|}{ Focus size $\left.{ }^{\mathrm{a}}\right)$} & \multicolumn{4}{|c|}{ Clinical sign ${ }^{b}$ ) } \\
\hline & $D-I$ & $\mathrm{D}-\mathrm{II}$ & D-III & D-IV & $D-I$ & D-II & D-III & D-IV \\
\hline 1 & - & - & - & - & 0 & 0 & 0 & 0 \\
\hline 2 & + & + & + & + & 0 & $\mathrm{O}$ & O & O \\
\hline 3 & $<0.2^{+}$ & 0.2 & $<0.2$ & 0.2 & 0 & 0 & $\mathrm{O}$ & 0 \\
\hline 4 & NT & NT & NT & NT & $S_{1-2}$ & $\mathrm{~S}_{1-2}$ & $\mathrm{~S}_{1-2}$ & $S_{1-2}$ \\
\hline 5 & $0.6-0.8$ & $0.6-0.8$ & $0.6-0.8$ & $0.6-0.8$ & $S_{2-D}$ & $S_{2-D}$ & $S_{2-D}$ & $S_{2-D}$ \\
\hline 6 & NT & NT & NT & NT & $\mathrm{D}$ & $\mathrm{D}$ & $\mathrm{D}$ & $\mathrm{D}$ \\
\hline 7 & $1.4-1.6$ & $1.2-1.4$ & $1.2-1.4$ & $1.2-1.4$ & & & & \\
\hline Titerc) $^{c}$ & $6.5 \times 10^{7}$ & $4.1 \times 10^{8}$ & $8.4 \times 10^{7}$ & $2.7 \times 10^{8}$ & $1.3 \times 10^{8}$ & $4.3 \times 10^{8}$ & $4.7 \times 10^{7}$ & $1.3 \times 10^{8}$ \\
\hline
\end{tabular}

* : A $0.1 \mathrm{ml}$ of serially ten fold diluted DVs was inoculated onto Vero cells and a $0.02 \mathrm{ml}$ of the aliquot material was inoculated into suckling mice intracerebrally.

a : Focus size, diameter in $\mathrm{mm}$;

- : undetectable

$+:$ detectable with a light microscope

${ }^{+}:$pin point size

NT : Not tested.

c : $\mathrm{EFFU} / \mathrm{ml}$ and $\mathrm{LD}_{50} / \mathrm{ml}$. $\mathrm{b}: \mathrm{C}$ inical signs are as follows;

$O:$ healthy

$\mathrm{S}_{1}$ : suspected paralysis or piloelection

$\mathrm{S}_{2}$ : paralysis of hind limbs

$\mathrm{D}:$ died.

\section{DISCUSSION}

Quantitative in vitro analysis in virology, such as the viral infectious titer and the neutralizing antibody titer, are usually expressed as the value of $\mathrm{TCID}_{50}, \mathrm{PFU}$ and NT. But these methods are unsuitable for the assay of viruses which cause little or no CPE to the cultured cells. For example, plaque assay method takes longer incubation time ${ }^{14)}{ }^{17)}$ in DV titration. Immunocytochemical method is another method to detect the viral infection. Since the first introduction of a fluorescent antibody method by Coons and Kaplan ${ }^{1)}$, it has been developed remarkably. However, this technique has some disadvantages. The stained specimen loses the fluorescence in a short time, and it requires a fluorescence microscope to observe the specimen. Nakane and Pierce ${ }^{13}$ ) developed the enzyme labeled antibody method. It is now as effective as the fluorescent antibody method owing to various improvements. In this method, specimens can be preserved semipermanently and requires only a conventional light microscope. Moreover, the location of the antigen can be examined with an electron microscope $^{9)}$. However, these methods have not considered the viral titration.

Igarashi and Mantani ${ }^{7)}$ stained the focus produced by viral infection with fluorescent antibody, and the viral titer was measured by counting the stained foci under a fluorescence 
microscope as the fluorescence focus forming unit (FFFU). Okuno et al. ${ }^{14)}$ modified the method to introduce an enzyme labeled antibody but their procedure had many steps and reagents. In their procedure, the foci must be counted in the small size. Therefore, it needs a light microscopic observation, and the observation is troublesome. Furthermore, it is useful only for the virus-cell system in which viral infection spread by cell to cell infection.

In the present study, we have stained the infectious focus with enzyme labeled antibody, by which the focus was counted easily with naked eye. This method is useful for any virus-cell system in which the virus replicate.

At first the EFFA was evaluated in its sensitivity, comparing with the PFA. For this evaluation, JEV was titrated because it was possible to assay the infectious titer by the both methods. When aliquots of the specimen were titrated by each method, the infectious titer was well coincided with each other. However, the focus size of the EFFA was larger than the plaque size of the PFA. Because, in the former system, marginal cells of plaques were in the early stage of the viral infection and were stained as viral antigen positive. Therefore foci were larger and were detected 1 to 2 days ealier than plaques.

Concentration of methylcellulose or agar in the overlay medium influences on plaque size and as the result, on the incubation time for plaque formation ${ }^{5)}$. In the present study, the concentration of $\mathrm{MC}$ in the overlay medium was better in range of $1.2-1.5 \%$ on the focus staining. From the reasons of sharpness, reproducibility of foci and handling easiness, $1.2 \%$ overlay medium was chosen in the following studies. This concentration was reasonable to the other report ${ }^{5)}$. By this concentration and incubation for 5 days, fine and reproducible foci of DV were obtained. But the plaque formation was insufficient during this incubation period. It took more than 7 days to form clear plaques under the MC concentration of 1.2 $1.5 \%$.

By the condition described above, infectious foci were detected after incubation for 3 days (Table 2 and 3). Focus size increased during the incubation. The focus was also detected on the 2nd day of incubation by light microscopy as reported by Igarashi and Mantani ${ }^{7)}$, and Okuno et al ${ }^{\mathbf{1 4})}$. However, counting foci with the naked eye was more accurate and easier than the counting with a light microscope.

Focus size of DVs adapted in SMB was similar to that of DVs adapted to Vero cells (Table 4). D-II wild type strains, which were isolated from human patients and were passed in $\mathrm{C} 6 / 36$ cells as few as possible, were titrated by the EFFA. The precise data will be reported in the following paper. In brief, these wild type strains could be titrated by the EFFA but could not by the SMBA, because they could not cause lethal infection to the mouse. These results indicate that the EFFA does not select the sources of viral material, 
therefore, is able to apply widely for the quantitation of wild type viruses.

The EFFA and the SMBA were compared for their sensitivity and the incubation time to estimate the viral titer. When an aliquot of DV specimen was inoculated into SMB, the mouse showed clinical signs 4 days after inoculation and died at 6 day. Thus, the infectious titer $\left(\mathrm{LD}_{50}\right)$ could be estimated later than the 6 th day. While it took 3 days' incubation to caliculate the infectious titer by the EFFA (EFFU). The infectious titers were almost equal in the both methods (Table 5).

Nakamichi ${ }^{12)}$ applied the EFFA for the morphological study of rubella virus (RV) replication. In that report he could count its infectious titer by the EFFA. This method was more simple and more rapid than the interference system of Parkman et al. ${ }^{15}$ ) for RV titration $^{12)}$.

Furthermore, the EFFA is applicable to the electron microscopy (IEM) changing the fixatives for the $\mathrm{IEM}^{12)}{ }^{18)}$. The specimen, prepared by this system has two advantages. 1) It is easy to approach to the virus infected cells, for they are positively stained by the immuno enzymatic staining and visible. 2) The viral infectious process is observed easily. The marginal area corresponds to the early stage of viral replication and the central area to the late stage of the replication.

\section{REFERENCES}

1) Coons, A.H. and Kaplan, M.H. : Localization of antigen in tissue cells ; improvements in a method for the detection on antigen by means of fluorescent antibody. J. Exp. Med., 91, 1 13, 1950.

2) Dulbecco, R. and Vogt, M. : Plaque formation and isolation of pure lines with poliomyelitis virus. J. Exp. Med., 99, 167 182, 1954.

3) Frasca, J.M. and Parks, V.P. : A routine technique for doublestaining ultrathin sections using uranyl and lead salts. J. Cell Biol., 25, 157 161, 1965.

4) Graham, R. C. and Karnovsky, M. J. : The early stages of absorption and injected horseradish peroxidase in the proximal tubules of mouse kidney: ultrastructural cytochemistry by a new technique. J. Histochem., 14, 291 302, 1966.

5) Hsue, J-Y. : Studies on the multiplication of Japanese encephalitis virus. I. Factors influencing plaque formation of Japanese encephalitis virus. J. Kansai Med. Univ., 28, S62 S86, 1976.

6) Huang, S-C. : Electron microscopic study of Dengue-4 virus. J. Kansai Med. Univ., 28, S114 S156, 1976.

7) Igarashi, A. and Mantani, M. : Rapid titration of dengue virus type 4 infectivity by counting fluorescent foci. Biken J., 17, 87 93, 1974.

8) Ito, T. : Multiplication of Japanese encephalitis virus in cultured mosquito cells (Culex pipiens var. molestus). J. Kansai Med. Univ., 29, 591 625, 1977. (in Japanese)

9) Kawarai, Y. and Nakane, P.K. : Localization of tissue antigens on the ultrathin sections with peroxidase labeled antibody method. J. Histochem., 18, 161 166, 1970.

10) Luft, J. H. : Improvements in epoxy resin embedding methods. J. Biophys. Biochem. Cytol., 9, 409 
414, 1961.

11) McLean, I. W. and Nakane, P.K. : Periodate-Lysin-Paraformaldehyde fixative a new fixative for immunoelectron microscopy. J. Histochem., 22, 1077 1083, 1974.

12) Nakamichi, A. : Kinetic and ultrastructural study of rubella virus replication. -An application of enzyme labeled antibody techniuqe- J. Kansai Med. Univ., 37, 487 510, 1985. (in Japanese)

13) Nakane, P. K. and Pierce, G. B., Jr. : Enzyme-labeled antibodies : preparation and application for the localization of antigens. J. Histochem. Cytochem., 14, 929 931, 1966.

14) Okuno, Y., Sasao, F., Fukunaga, T. and Fukai, K. : An application of PAP (peroxidase-antiperoxidase) staining technique for the rapid titration of dengue virus type 4 infectivity. Biken J., 20, 29 33, 1977.

15) Parkman, P.D., Buescher, E. L. and Artenstein, M. S. : Recovery of rubella virus from army recruits. Proc. Soc. Exp. Biol. Med., 111, 225 230, 1962.

16) Reed, L. J. and Muench, H. : A simple method of estimating fifty percent endpoints. Am. J. Hyg., 27, 493 497, 1938.

17) Schulze, I. T. and Schlesinger, R.W. : Plaque assay of Dengue and other group B arthropod born viruses under methylcellulose overlay media. Virology, 19, 40 48, 1963.

18) Tanimura, E. : Approaches to the virus infected cells -Application of immuno electron microscopy-. J. Clin. Electron Microscopy, 17, 604 605, 1984.

\section{LEGEND FOR FIGURES}

Fig. 1 : Titration of JEV by the EFFA (upper 2 rows) and by the PFA (lower 2 rows). A $0.1 \mathrm{ml}$ of serially ten fold diluted virus was inoculated into each well. Immuno peroxidase positive infectious foci appear in a doughnut-like stain (upper 2 rows). Infectious foci are also countable by clear plaques (lower 2 rows). No differences of viral titer are found between the EFFA and the PFA. The plate was stained 5 days after inoculation. $\mathrm{C}:$ mock infection.

Fig. 2 : Titration of D-IV by the EFFA and by the PFA. Vero cell passed D-IV was serially tenfold diluted and a $0.1 \mathrm{ml}$ of each was inoculated to each well. After 5 days of incubation, cells were stained either by EFFA (upper 2 rows) or by the PFA (lower 2 rows). Immuno peroxidase positive foci are stained homogeneously (not ring form, upper 2 rows), while plaques did not formed (lower 2 rows).

Fig. 3 : Micrographs of immuno peroxidase positive foci in the well. Three days (a) and 5 days (b) after D-II inoculation, the cells were stained. The foci were photographed from the backside of the plate. Scales indicate $0.5 \mathrm{~mm}$.

Fig. 4 : Electron micrograph of a focus of D-II. Four days after inoculation, the infectious focus was fixed with $2 \% \mathrm{GA}$ and immuno peroxidase stained by the EFFA. Tubular structures and vacuoles which are typically found in the togavirus infected cells, are heavily stained. Arrows indicate DV particles in the vacuoles. Scale indicates $500 \mathrm{~nm}$. 
$\log _{10}$ Reciprocal JEV dilution

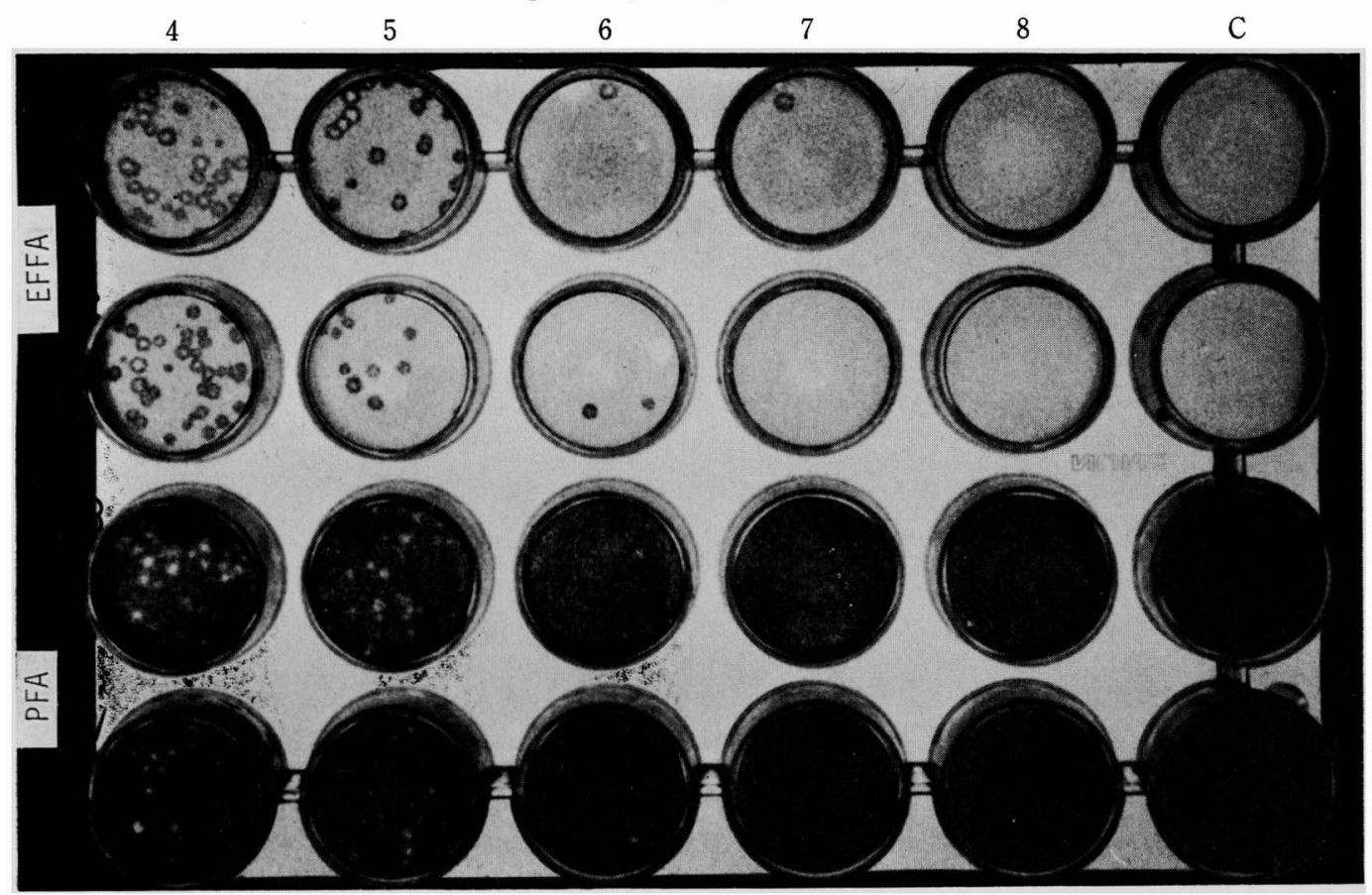

Fig. 1

$\log _{10}$ Reciprocal D-IV dilution

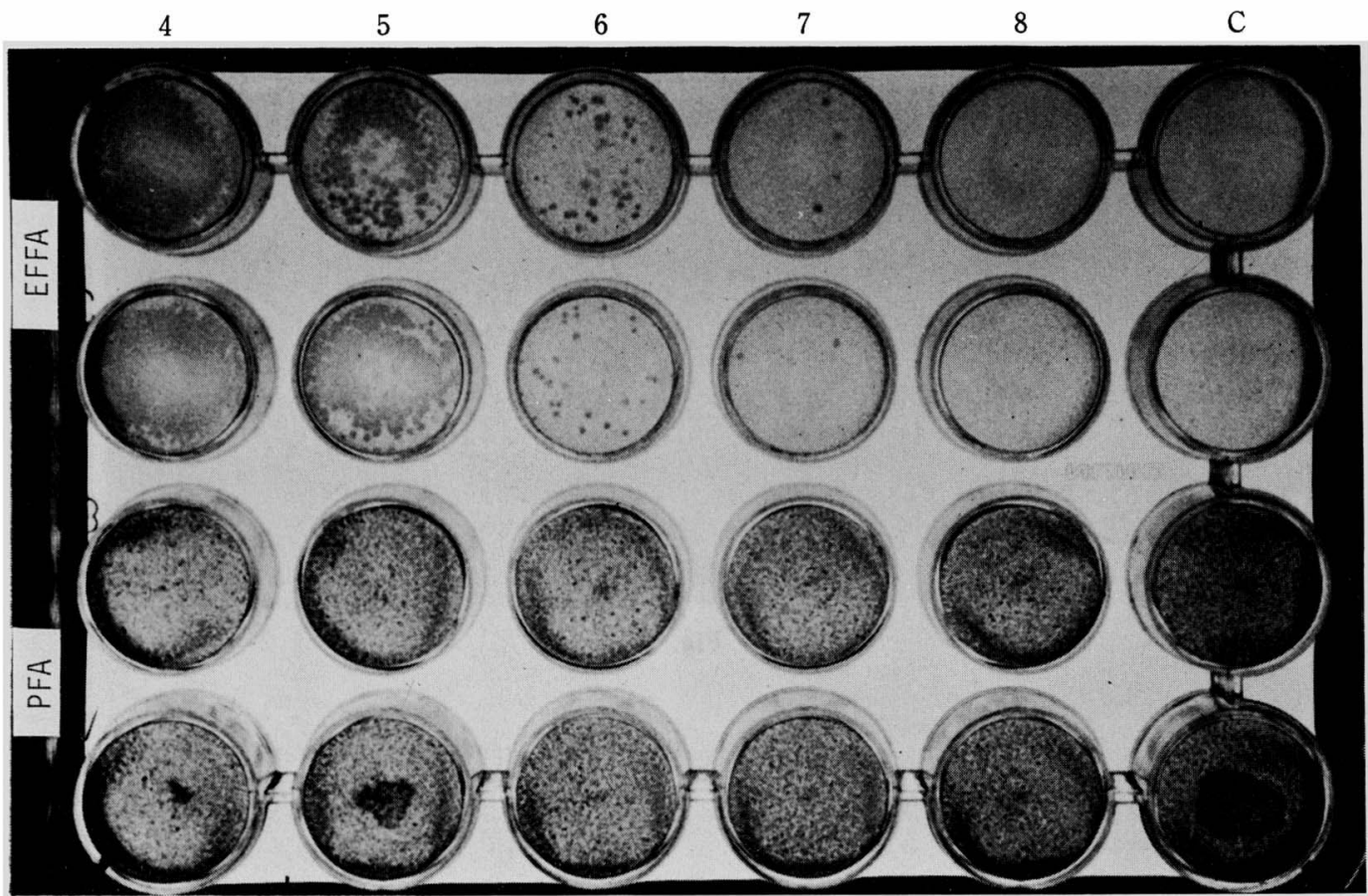

Fig. 2

Supplement to J.Kansai Med. Univ., Vol. 38, Dec. 1986 

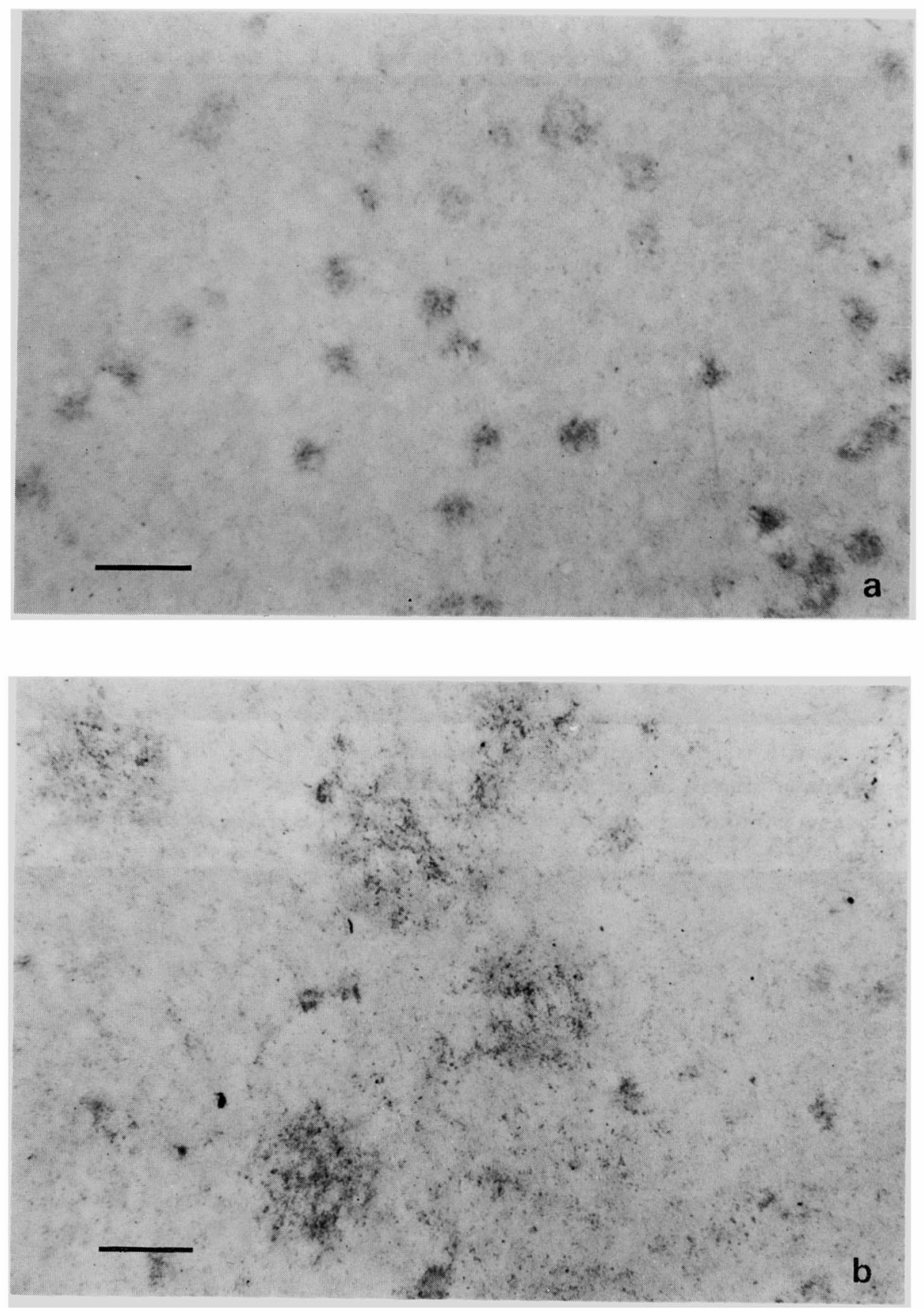

Fig. 3 


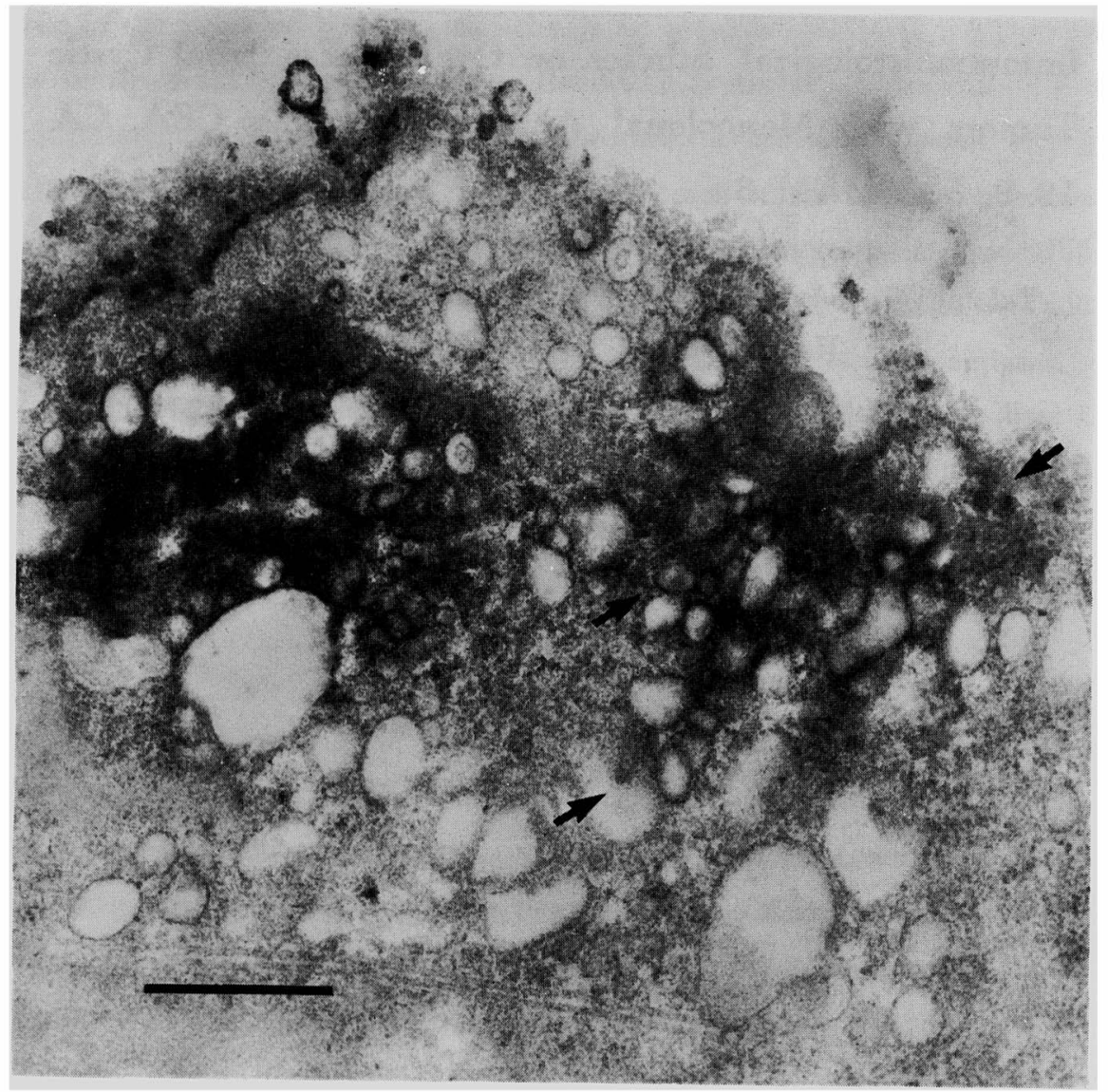

Fig. 4 